\title{
Correction to: Oxidative dissolution of silver nanoparticles by synthetic manganese dioxide investigated by synchrotron X-ray absorption spectroscopy
}

\section{Bruce A. Manning • Sushil R. Kanel • Edgar Guzman •}

Seth W. Brittle • Ioana E. Pavel

Published online: 14 December 2019

(C) Springer Nature B.V. 2019

\section{Correction to: J Nanopart Res}

https://doi.org/10.1007/s11051-019-4656-5

The original version of this article unfortunately contained a mistake. The equation was incorrectly presented.

The correct equation is shown below:

$\mathrm{AgNO}_{3}+\mathrm{NaBH}_{4}=\mathrm{Ag}^{0}+{ }^{1} /{ }_{2} \mathrm{H}_{2}+{ }^{1} /{ }_{2} \mathrm{~B}_{2} \mathrm{H}_{6}+\mathrm{NaNO}_{3}$

Publisher's note Springer Nature remains neutral with regard to jurisdictional claims in published maps and institutional affiliations. 